\title{
STUDIES UPON THE MECHANISM OF RESERPINE- INDUCED ARREST OF EGG TRANSPORT IN THE MOUSE OVIDUCT
}

\author{
I. THE EFFEGT OF HORMONE REPLACEMENT
}

\author{
K. E. KENDLE AND J. P. BENNETT* \\ B.D.H. (Research) Ltd, Borough Road, Godalming, Surrey
}

(Received 19th October 1968)

\begin{abstract}
Summary. The position of mouse eggs in the reproductive tract was determined following the administration of various doses of reserpine by the intraperitoneal route on Day 1 of pregnancy. High doses caused arrest of egg transport, while lower doses caused delay. The possibility that reduced hormone secretion is responsible was investigated by administration of ovarian, hypophysial and thyroid hormones. The failure of these various treatments to reverse the reserpine-induced arrest of egg transport suggests that alterations in hormone secretion are not the primary cause of the arrest.
\end{abstract}

\section{INTRODUCTION}

It has been shown in the mouse (Beatty, 1951), rat (Noyes \& Dickmann, 1960) and a number of other species that, for normal fertility, the fertilized egg must enter the uterus at the 'correct' stage of development relative to that of the endometrium, within fairly narrow limits. Normal functioning of the oviduct, which contains the eggs for the first 3 days of pregnancy in the mouse (Burdick, Whitney \& Emerson, 1942; Bennett \& Kendle, 1967; Humphrey, 1968), is of prime importance in the reproductive process. Although the oviduct contains a considerable amount of smooth muscle (Burdick et al., 1942), few investigations have been carried out into effects upon the egg transport of pharmacological agents which alter smooth muscle activity.

Bennett \& Kendle (1967) have described the arrest of egg transport in the mouse oviduct by reserpine, a tranquillizer and hypotensive agent (Text-fig. 1). Several possible mechanisms of action were postulated because of the wide spectrum of the pharmacological activity of reserpine. The minimum dose producing significant delay in the rate of egg transport when given on Day 1 of pregnancy has now been determined and attempts made to reverse this arrest by hormone administration. The significance of these experiments in relation to the mechanism of reserpine-induced arrest of egg transport is discussed.

* Present address: Institute of Hormone Biology, Syntex Research Centre, Palo Alto, California, U.S.A. 


\section{MATERIALS AND METHODS}

A stock solution containing $3.2 \mathrm{mg} / \mathrm{ml}$ of reserpine was prepared as described previously (Bennett \& Kendle, 1967) and diluted when necessary with distilled water immediately before use to adjust the dose volume to $10 \mathrm{ml} / \mathrm{kg}$ body weight. A similar solution without the reserpine was prepared as a vehicle control.

Oestrone, oestradiol benzoate, oestriol or progesterone were dissolved in $0.1 \mathrm{ml}$ of a mixture of $20 \%$ ethyl oleate and $80 \%$ arachis oil immediately before use, while pregnant mares serum gonadotrophin (PMSG; Paines and Byrn Ltd), human chorionic gonadotrophin (HCG; Organon Ltd) and adrenocorticotrophic hormone (АСTH; Organon Ltd) were dissolved in $0.2 \mathrm{ml}$ distilled water immediately before use. Thyroxine sodium was also dissolved in distilled water immediately before use, and the dose volume adjusted to $10 \mathrm{ml} / \mathrm{kg}$ body weight.

Specific pathogen-free albino mice were obtained from colonies in our own

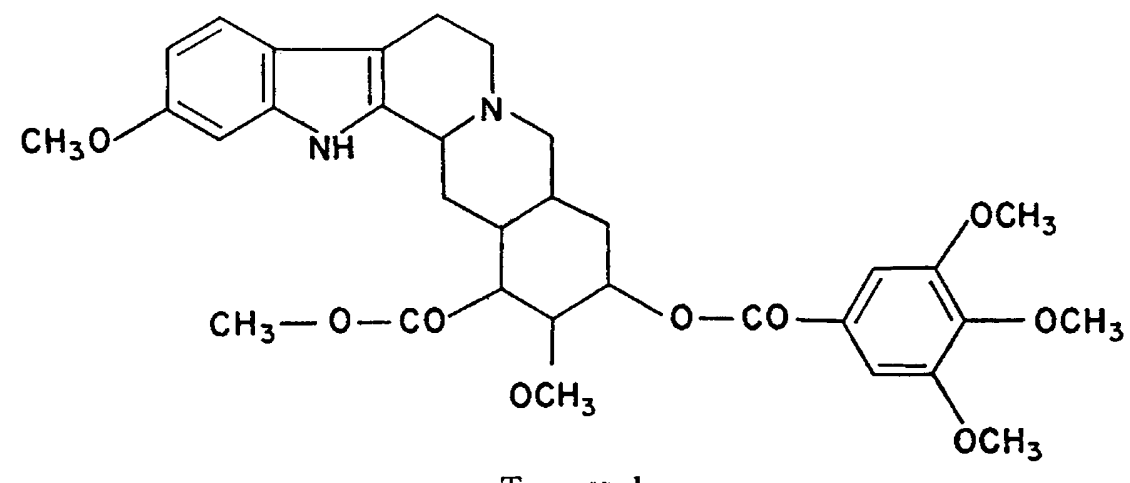

Text-pIG. 1

laboratories and housed at a minimum temperature of $22^{\circ} \mathrm{C}$ with artificial lighting from 06.00 to 21.00 hours. Mature females were placed with fertile males and examined each morning for vaginal plugs. The day on which the vaginal plug was observed was designated Day 1 of pregnancy. The effect of various dose levels of reserpine given on Day 1 upon the rate of egg transport was examined. The drug was administered by intraperitoneal injection to six groups of thirty animals, while another group was given the vehicle as a control and a further group was untreated. Ten animals from each group were killed on the 2nd, 3rd and 4th days of pregnancy and, in addition, ten undosed control animals were killed on Day 1. At autopsy, the position of eggs in the reproductive tract was determined. The method used was the same as that described previously (Bennett \& Kendle, 1967), except that the position of each individual egg was determined and expressed as a percentage of the entire tube length.

In the hormone replacement experiments, animals given $4 \mathrm{mg} / \mathrm{kg}$ reserpine by the intraperitoneal route on Day $I$ of pregnancy were divided into groups of five and given various doses of the hormones on Days 1, 2 and 3. One group of animals in each experiment was given the reserpine vehicle only, while a further group was given reserpine on Day 1 and the hormone vehicle by the appropriate route on Days 1, 2 and 3. Oestrone, oestradiol benzoate, oestriol, 
progesterone and thyroxine were given by the subcutaneous route, while a combination of PMSG and HCG, and ACTH were given by the intraperitoneal route.

All animals were killed on Day 4 of pregnancy and the positions of the eggs determined within the reproductive tract. Since administration of reserpine causes severe hypothermia (Plummer, Earl, Schneider, Trapold \& Barret, 1954), oesophageal temperatures of all mice were measured immediately before killing using a thermocouple thermometer (Ellab, Elektro Laboratories, Copenhagen).

\section{RESULTS}

The effect of various doses of reserpine given on Day 1 of pregnancy by the intraperitoneal route upon the rate of egg transport in the mouse oviduct is shown in Text-fig. 2. Administration of the reserpine vehicle or a dose of $1 \mathrm{mg} / \mathrm{kg}$ reserpine did not alter the rate of egg transport, normal blastocysts

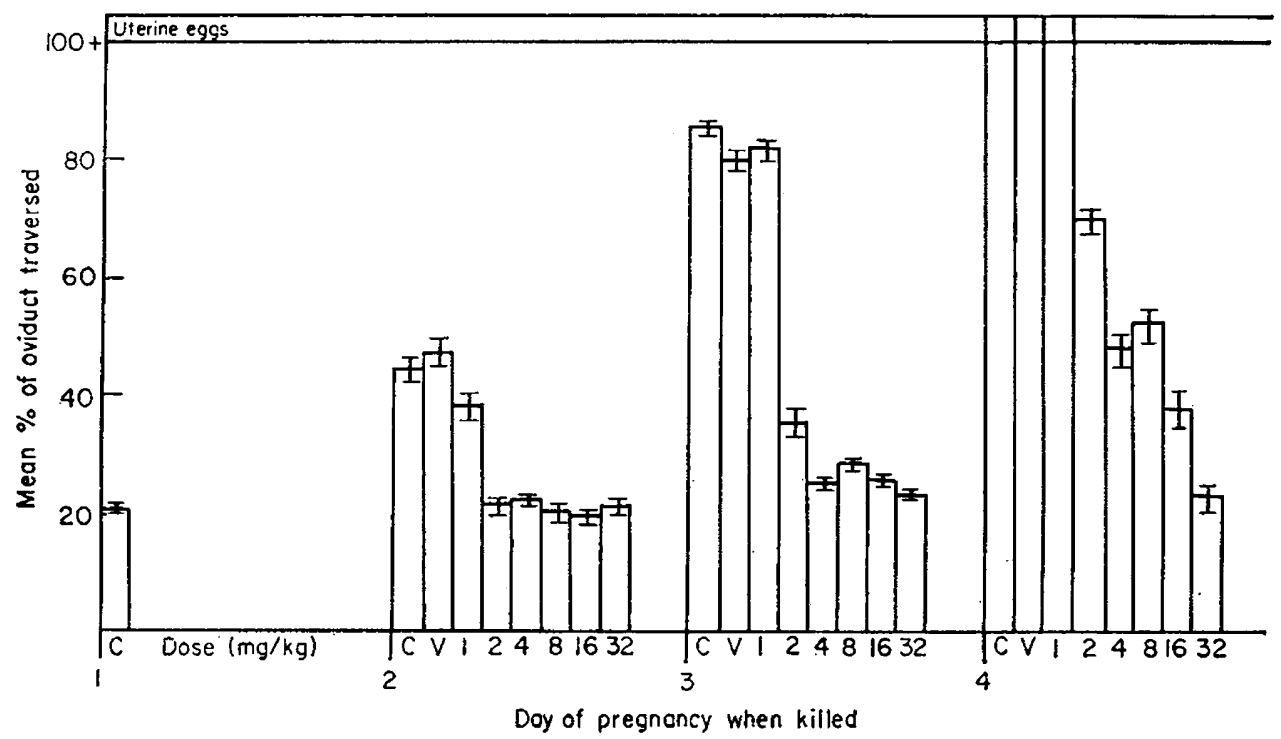

TEXT-FIG. 2. The position of eggs in the mouse reproductive tract at autopsy on Days 2, 3 and 4 of pregnancy following the intraperitoneal administration of various doses of reserpine on Day 1. G: Control; V: Vehicle.

being recovered from the uterus at autopsy on Day 4 of pregnancy. A dose of $2 \mathrm{mg} / \mathrm{kg}$ caused approximately $24 \mathrm{hr}$ delay, while doses of 4,8 and $16 \mathrm{mg} / \mathrm{kg}$ caused approximately $48 \mathrm{hr}$ delay in the movement of eggs through the oviduct. Eggs were observed in the position normally seen on Day 1 in control animals, at autopsy on Day 4 of pregnancy following a dose of $32 \mathrm{mg} / \mathrm{kg}$. The mean number of eggs recovered per mouse in the various treatment groups ranged from $6 \cdot 8$ to $9 \cdot 3$, the variation occurring at random.

As observed in previous experiments (Bennett \& Kendle, 1967), the development of the eggs was also delayed for approximately the same duration as their transport. For example, following a dose of $32 \mathrm{mg} / \mathrm{kg}$ of reserpine the eggs were 
TABLE 1

EFFECT OF OVARIAN HORMONES UPON THE RATE OF EGG TRANSPORT IN RESERPINE-TREATED MICE WHEN GIVEN BY SUBGUTANEOUS INJEGTION ON DAYS 1, 2 AND 3 OF PREGNANCY

\begin{tabular}{|c|c|c|c|c|c|}
\hline & $\begin{array}{c}\text { Dose of } \\
\text { steroid } \\
0 \cdot 1 \mathrm{mll} \\
\text { mouse/day }\end{array}$ & Oestrone & $\begin{array}{c}\text { Oestradiol } \\
\text { benzoate }\end{array}$ & Oestriol & Progesterone \\
\hline Reserpine vehicle only & & $100+$ & $100+$ & $100+$ & $100+$ \\
\hline Reserpine + steroid vehicle & & $24 \pm 1$ & $30 \pm 3$ & $28 \pm 1$ & $25 \pm 0.6$ \\
\hline Reserpine + steroid & $\begin{array}{c}0 \cdot 1 \mu \mathrm{g} \\
1 \mu \mathrm{g} \\
10 \mu \mathrm{g} \\
100 \mu \mathrm{g} \\
1 \mathrm{mg} \\
10 \mathrm{mg}\end{array}$ & $\begin{array}{l}29 \pm 1 \\
38 \pm 4 \\
40 \pm 4 \\
54 \pm 5 \\
25 \pm 1\end{array}$ & $\begin{array}{l}39 \pm 4 \\
30 \pm 2 \\
44 \pm 4 \\
42 \pm 4 \\
37 \pm 3 \\
\end{array}$ & $\begin{array}{l}24 \pm 1 \\
23 \pm 1 \\
26 \pm 1 \\
25 \pm 1 \\
24 \pm 0.5\end{array}$ & $\begin{array}{l}34 \pm 4 \\
39 \pm 4 \\
29 \pm 2 \\
24 \pm 2\end{array}$ \\
\hline
\end{tabular}

The values represent the mean percentage of the oviduct traversed by the contained eggs \pm S.E. on Day 4 in groups of five mice given $4 \mathrm{mg} / \mathrm{kg}$ of reserpine by the intraperitoneal route on Day 1.

The symbol $100+$ represents ova recovered from the uterus.

found in the position that would be expected on Day 1 in the control animals and were still at the one-cell stage, probably due to retarded development rather than delayed fertilization. The same effect could be produced by

TABLE 2

EFFECT OF GONADOTROPHINS UPON THE RATE OF EGG TRANSPORT IN RESERPINE-TREATED MICE WHEN GIVEN BY SUBGUTANEOUS INJEGTION ON DAYS 1, 2 AND 3 OF PREGNANCY

\begin{tabular}{c|c|c}
\hline \multicolumn{2}{c|}{$\begin{array}{c}\text { Dose } \\
\text { (i.u./0.2 ml/mouse/day })\end{array}$} & $\begin{array}{c}\text { Mean \% } \\
\text { oviduct } \\
\text { traversed } \pm S . E .\end{array}$ \\
\hline PMSG & $H C G$ & $57 \pm 5$ \\
Vehicle & & $27 \pm 2$ \\
$0 \cdot 4$ & & $66 \pm 5$ \\
$4 \cdot 0$ & & $40 \pm 4$ \\
40.0 & & $32 \pm 4$ \\
$400 \cdot 0$ & & $34 \pm 1$ \\
& Vehicle & $25 \pm 3$ \\
& $0 \cdot 1$ & $35 \pm 2$ \\
& $1 \cdot 0$ & $27 \pm 1$ \\
Vehicle & $10 \cdot 0$ & $25 \pm 3$ \\
$0 \cdot 4$ & Vehicle & $31 \pm 2$ \\
$4 \cdot 0$ & $0 \cdot 1$ & $22 \pm 1$ \\
40.0 & $1 \cdot 0$ & $31 \pm 3$ \\
400.0 & $10 \cdot 0$ & $27 \pm 1$ \\
& $100 \cdot 0$ & $32 \pm 1$ \\
\hline
\end{tabular}

The values represent the mean percentage of the oviduct traversed by the contained eggs \pm S.E. on Day 4 in groups of five mice given $4 \mathrm{mg} / \mathrm{kg}$ of reserpine by the intraperitoneal route on Day 1. 
administration of reserpine late on Day 1 of pregnancy after fertilization had taken place.

The dose of $4 \mathrm{mg} / \mathrm{kg}$ reserpine was selected for further study as the minimum dose causing at least $48 \mathrm{hr}$ delay in the transport of eggs. Table 1 summarizes the effect of exogenous ovarian hormones upon the arrest of egg transport produced by this dose of reserpine. None of the ovarian hormones restored the rate of egg transport to normal and the results given in Table 2 show that various doses of gonadotrophins alone or in combination also failed to reverse the reserpine-induced arrest of egg transport.

Doses of $0 \cdot 1,1$ and 10 i.u. ACTH and 1.25 and $6.25 \mathrm{mg} / \mathrm{kg}$ of L-thyroxine sodium also did not counteract the arrest of egg transport in reserpine-treated animals.

All animals treated with reserpine showed hypothermia, the degree being related to the dose level even in those animals receiving $\mathbf{L}$-thyroxine sodium.

\section{DISGUSSION}

Administration of reserpine inhibits pituitary gonadotrophin secretion and ovarian oestrogen production. This is manifest as effects on oestrus (Cranston, 1958), ovulation (Purshottam, 1962; Brown, 1966; Hopkins \& Pincus, 1963), vaginal histology (Benson, 1958), milk secretion (Meites, Nicoll \& Talwalker, 1959), pituitary histology (Pasteels, 1961) and implantation (Mayer \& Meunier, 1959; Mayer, Meunier \& Thevenot-Duluc, 1960).

Reserpine has also been shown to delay or arrest egg transport in the mouse (Bennett \& Kendle, 1967). The hypothesis that the observed arrest was directly due to lack of ovarian oestrogen production was tested by replacement experiments. Each of the natural oestrogens was tested at a range of dose levels in an attempt to restore the rate of egg transport to normal. Although it is probable that reserpine administration causes increased progesterone secretion, the effect of exogenous progesterone was also examined. None of these treatments was effective in producing normal rates of egg transport in reserpine-treated mice. Gonadotrophin replacement studies were then undertaken to examine whether circulating gonadotrophin levels had some direct effect on oviduct musculature or, alternatively, that gonadotrophin administration could produce an essential ovarian secretion not fully represented by the steroid replacement experiments. However, daily administration of PMSG and HGG separately and in combination was ineffective in maintaining normal egg transport rates in reserpine-treated mice. These experiments indicate that alterations in gonadal and gonadotrophic hormone secretion rates are not the sole mechanism of reserpine-induced arrest of egg transport in the mouse.

Maickel, Westermann \& Brodie (1961) and many others have shown that reserpine administration causes hypersecretion of ACTH with consequent pituitary depletion. Such animals are unable to respond to stress by further release of АСтн. The possibility that tubal transport might be arrested due to the inability of the animal to secrete additional quantities of ACTH was, therefore, also investigated. АCTH, however, failed to reverse the resperine-induced arrest of egg transport. 
Taylor \& Fregley (1962) showed that thyroxine, but not TsH, reversed the hypothermic activity of reserpine. This finding suggests that thyroid activity and its ability to respond to TSH may be reduced by reserpine treatment. The failure of L-thyroxine sodium injections to reverse the arrest of egg transport, however, would indicate that this arrest is not primarily due to drug-induced hypothyroidism. It is of interest that L-thyroxine sodium treatment did not reverse the hypothermia which followed reserpine treatment in our mice.

It is concluded that, although reserpine produces profound changes in endocrine activity, these changes are not solely responsible for the arrest in egg transport observed.

\section{REFERENCES}

Beatty, R. A. (1951) Transplantation of mouse eggs. Nature, Lond. 168, 995.

BenNeTr, J. P. \& Kendle, K. E. (1967) The effect of reserpine upon the rate of egg transport in the Fallopian tube of the mouse. F. Reprod. Fert. 13, 345.

BENSON, G. K. (1958) Effect of reserpine on mammary gland involution and on other organs in the rat. Proc. Soc. exp. Biol. Med. 99, 550.

BRown, P. S. (1966) The effect of reserpine, 5-hydroxytryptamine and other drugs on induced ovulation in immature mice. 7. Endocr. 35, 161.

Burdick, H. O., WhitNey, R. \& Emerson, B. (1942) Observations on the transport of tubal ova. Endocrinology, 31, 100.

Cranston, E. M. (1958) Effect of tranquillizers and other agents on the sexual cycle of mice. Proc. Soc. exp. Biol. Med. 98, 320.

Hopkins, T. F. \& Pincus, G. (1963) The anti-ovulatory effects of resperine when administered to immature rats. Fedn Proc. Fedn Am. Socs exp. Biol. 22, 506.

HumphrEy, K. W. (1968) Observations on the transport of ova in the oviduct of the laboratory mouse. 7. Endocr. 40, 276.

Maickel, R. P., Westermann, E. O. \& Brodie, B. B. (1961) Effects of reserpine and cold exposure on pituitary-adrenocortical function in rats. 7. Pharmac. exp. Ther. 134, 167.

Mayer, G. \& Meunier, J. M. (1959) Réserpine et progestation chez la ratte. Survie des oufs en phase latente et ovoimplantations normales ou retardées, provoquées par l'œstrogène. C.r. hebd. Séanc. Acad. Sci., Paris, 248, 3355.

Mayer, G., Meunier, J. M. \& Thevenot-Duluc, A. J. (1960) Prolongation de la grossesse par retards de nidation obtenus chez la ratte par administration de réserpine. Annls Endocr. 21, 1.

Mertes, J., Nicoll, C. S. \& Talwalker, P. K. (1959) Effects of reserpine and serotonin on milk secretion and mammary growth in the rat. Proc. Soc. exp. Biol. Med. 101, 563.

Noyes, R. W. \& Dickmann, Z. (1960) Relationship of ovular age to endometrial development. $\mathcal{F}$. Reprod. Fert. 1, 186.

Pasteels, J. L. (1961) Comparaison entre l'action des androgènes et de la réserpine sur l'hypophyse et la glande mammaire chez le rat. Annls Endocr. 22, 257.

Plummer, A. J., Earl, A., Schneider, J. A., Trapold, J. \& Barret, W. (1954) The pharmacology of Rauwolfia alkaloids including reserpine. Ann. N.Y. Acad. Sci. 59, 8.

Purshottam, N. (1962) Effects of tranquillisers on induced ovulation in mice. Am. J. Obstet. Gynec. 88, 1405.

TAYLOR, R. E. \& FREGLEY, M. J. (1962) Effect of reserpine on body temperature regulation of the rat. 7. Pharmac. exp. Ther. 138, 200. 